\title{
PGPR: Renewable Tool for Sustainable Agriculture
}

\author{
Kusum Sharma $^{1 *}$, Swati Sharma ${ }^{1}$ and S. Rajendra Prasad ${ }^{2}$ \\ ${ }^{1}$ Integral University, Lucknow, ${ }^{2}$ UAS, Bangalore, India \\ *Corresponding author
}

\begin{tabular}{|l|}
\hline Ke y w o r d s \\
PGPR, Sustainable \\
agriculture, \\
Biofertilizers
\end{tabular}

\section{A B S T R A C T}

In developing countries like India agriculture contributes major share of national income. A huge amount of chemical fertilizers require to enhance crop yield. The indiscriminate use of chemical fertilizers and pesticides affect not only the soil sustainability but also imparted the negative impact on environment and human health, besides increasing the input cost for crop production especially for the marginal farmers. Now a day, environment friendly plant growth promoting rhizobia (PGPR) has emerged as an alternative tool to minimise the application of chemical fertilizers. Many beneficial plant growth promoting rhizobacterial strain, can promote plant growth and yield are considered as PGPR. PGPR can promote plant growth by several mechanism including: (i) Synthesis of phytohormones or plant nutrients, (ii) Mobilizing of complex soil compounds and makes them available to plants, (iii) Provide stability under stress condition thereby counteracting the negative impacts of stress, (iv) defence against many plant pathogens and reduce plant diseases. In agriculture, microbes can be applied as biofertilizers. Worldwide several PGPR have been used as biofertilizers to increase plant growth promotion, yield of crop and enhance soil fertility hence PGPR contribute to more sustainable agriculture.

\section{Introduction}

Excessive and indiscriminate use of chemical fertilizers and pesticides creates negatives impacts on soil fertility, environment as well as on human health. Use of disproportionate and huge chemical fertilizers remain inaccessible to plants (Bhandari, 2014), and leads to decreasing organic carbon in soil, loss of beneficial microbial flora in soil, increasing acidity and alkalinity and hardening of soil. Increasing use of chemical fertilizers led to high cost in vegetable and grain production and creates pollution to agricultural environment as well as adversely affecting the soil and livelihood of marginal farmers and large section of populations; therefore, it has become essential to use bio-fertilizers as supplements or substitutes for chemical nitrogen fertilizers Rajasekaran et al., (2012). PGPR has emerged as an alternative tool to minimise the application of agriculture chemical fertilizers for sustainable agricultural practices. Now a day a great attention is being given to reduce application of expensive inorganic fertilizers, minimizing 
environmental pollution through reducing doses of nitrogenous and phosphorus fertilizers by using biofertilized farming system (El- Nagdy et al., 2010).

\section{Plant growth promoting rhizobacteria}

Some beneficial bacteria found in rhizospheric region of plants, that stimulate plant growth (Kloepper et al., (1991). Stimulatory effect of plant growth promotion may be due to the direct mechanism or indirect mechanism. Direct mechanisms may act on the plant itself and affect growth by means of plant growth regulators like Phytoharmone production (Noel et.al 1996), enhancement of availability of some inorganic (Kapulnik, 1991) liberation of phosphates and micronutrients, nitrogen fixation and stimulation of disease-resistance mechanisms (Lazarovits and Nowak, 1997). Indirect effects arise from PGPR altering the root environment and ecology (Glick, 1995). For example, microbes act as biocontrol agents and inhibit plant pathogens thereby reducing pant diseases, and producing antibiotic substances that destroy toxic bacteria (Lazarovits and Nowak, 1997). The role of several rhizospheric bacteria belonging to the genera Pseudomonas The role of several rhizospheric bacteria belonging to the genera Pseudomonas, Rhizobium, Enterobacter and Bacillus (Sorty et al., 2016), Azotobacter (Kizilkaya, 2009), Azospirillum (Cassan et al., 2014), Bradyrhizobium (Soe et al., 2012) Methylobacterium (Meena et al., 2012), Trichoderma (Ahmad et al., 2015) and cyanobacteria (Singh et al., 2011) in plant growth promotion and mitigation of multiple kinds of abiotic stresses has been documented.

\section{Roles of PGPM in agriculture sustainability}

A long-standing recognition of microbial use and application for making agriculture sustainable is a matter of interest that have generated keen attention of scientific research towards the PGPR (Dubey et al., 2016). The exploitation of beneficial microbes may improve agriculture system with economically sound production of human food Maheshwari (2010). PGPR as biofertilizers along with application of a biocontrol agent or biopesticides to control pests and pathogens have been considered as the best practices for sustaining agriculture (Mishra et al., 2015). Biofertilizers from microorganisms can replace chemical fertilizers $(\mathrm{N}, \mathrm{P}$ and $\mathrm{K}$ ) to increase crop production. In principle, biofertilizers are less expensive and are more environmentally friendly than chemical fertilizers.

\section{Improving soil fertility}

The fertile soil is defined as the soil that provided with proper physical, chemical and biological need for optimum growth of plants (Abbott and Murphy, 2007). Excessive and indiscriminate use of synthetic chemical fertilizers leads to deterioration and misbalancing of chemical and biological properties of soil (Liang et al., 2013). SOC (soil organic content) is an important indicator of soil quality (Islam and Weil 2000). PGPR have different kind of mechanisms that directly help to increase the SOC and maintain soil fertility. According to Tewari and Arora (2014), under salt stress and drought condition, Exopolysacharide producing bacteria are found to be very helpful to increasing crop yield.

\section{Phytohormone production}

Plant growth regulators, are used to regulate the growth of plants and are important measures for boosting agricultural production. PGPR have a kind of different types of mechanisms to produce phytohormones such as IAA, GA, cytokinins, and ethylene. IAA is a most common occurring phytohormone found in plants and involve in a wide range of 
processes for the growth and development of plants. It has been reported that that auxinproducing Bacillus spp. have a positive effect on Solanun tuberosum's growth (Ahmed and Hasnain, 2010). Phytohormone gibberellins involve in a number of various plant growth promotion activities, major function of gibberellins is shoot elongation. According to (Khan, 2014) tomato plant treated with gibberellins producing bacteria Sphingomonas sp. LK11 strain have a significant increase in various growth characteristics. Liu (2012) reported that Inoculation of cytokinin producing Bacillus subtillus in Thuja seedling results in more resistant to drought stress.

\section{Suppressing phytopathogens}

Worldwide phytopathogens affecting plant health are a major and chronic threat to crop production and ecosystem stability. However, use of huge amount of chemical fertilizers in the field of agriculture cause development of pathogen resistance to the applied agents and their non target environmental impacts (Gerhardson, 2002.). Therefore use of biological control is considered as an alternative way of reducing the use of chemicals in agriculture (Gerhardson, 2002). All crop pests (pathogens, arthropods, and weeds) cause preharvest losses of $42 \%$ and an additional $10 \%$ loss after harvest (Fletcher et al., 2006).

Indiscriminate use of pesticides to reduce the plant diseases causes various ecological issues. PGPR belonging to the genus Bacillus have got recognition for wider biocontrol activity against pests. Bacillus thuringiensis (Bt) covers $90 \%$ of the biopesticide market in the USA (Chattopadhyay et al., 2004). Besides Bacillus, genus Pseudomonas, Serratia and Arthrobacter have also been reported as BCA (Joseph et al., 2007). Strains of Pseudomonas are known to produce a variety of antibiotics or antifungal metabolites directly involved in the suppression of diseases (Mishra and Arora, 2012). Biocontrol agents such as PGPR and PGPF (Plant growth promoting Fungi) offer the advantages of higher selectivity and lower or no toxicity in comparison to conventional chemical pesticides (Mishra et al., 2015).

\section{Abiotic stress mitigation}

Abiotic stress is a major limiting factor for decline in agriculture productivity. Drought, low/high temperature, salinity and acidic conditions, light intensity, submergence, anaerobiosis and nutrient starvation (BaileySerres, 2008) are the major abiotic stress factors. Worldwide, out of 5.2 billion hectares of agriculture land, 3.6 billion hectares are affected by soil erosion, soil degradation and salinity (Riadh et al., 2010). Plant-microbe interaction provide fundamental support to the plant in acquiring nutrients and disease resistant and abiotic stress (Turner et al., 2013). Microbial interaction to the plants evokes a various kind of local and systemic response that improves plant's metabolic capability to resist against abiotic stress (Nguyen et al., 2016). Work on plant-microbe interactions at biochemical, physiological and molecular levels established that microbial associations largely direct plant responses toward stresses (Farrar et al., 2014).

\section{Rhizoremediation}

A process of removal of soil contaminants by the help of microbes found in rhizosphere is termed as Rhizoremediation (Segura et al., 2013). For the removal of pollutants from the contamination site, the technique is developing as a prominent method by using of combined degradative potential plants and their associative rhizospheric microorganisms (Zhuang et al., 2007). Microbes can produce a wide range of hydrolytic enzymes that accelerate the degradation process and helps in eco-restoration of polluted site (Daane et al., 2001) (Fig. 1 and Table 1). 
Table.1

\begin{tabular}{|l|l|l|l|}
\hline \multicolumn{1}{|c|}{ PGPR } & \multicolumn{1}{|c|}{ Mechanism } & \multicolumn{1}{c|}{ Application } & \multicolumn{1}{c|}{ Reference } \\
\hline $\begin{array}{l}\text { Azospirillum } \\
\text { Azotobacter } \\
\text { Frankia, } \\
\text { Mezorhizobium, } \\
\text { sinorhizobium } \\
\text { Pseudomonas } \\
\text { Rhizobium }\end{array}$ & Nitrogen Fixation & $\begin{array}{l}\text { Enhance plant growth } \\
\text { and development and } \\
\text { suppress the attack of } \\
\text { phytopathogens }\end{array}$ & $\begin{array}{l}\text { Dobbelaere } \text { et al., 2001; } \\
\text { Wani } \text { et al., 2007; Ahemad } \\
\text { and Kibret 2014 }\end{array}$ \\
\hline $\begin{array}{l}\text { Bacillus } \\
\text { Mycorhhiza } \\
\text { Pseudomonas } \\
\text { Rhizobium } \\
\text { Serretia }\end{array}$ & $\begin{array}{l}\text { Phosphate } \\
\text { solubilising } \\
\text { Bioferilizers }\end{array}$ & $\begin{array}{l}\text { Increase crop production } \\
\text { and yield, mineralization } \\
\text { of insoluble form of } \\
\text { phosphate and recycling } \\
\text { of nutrients. Also } \\
\text { suppress many plant } \\
\text { diseases. }\end{array}$ & $\begin{array}{l}\text { Cibichakravarthy } \text { et al., } \\
\text { 2012; Sarathambal } \text { et al., } \\
\text { 2014; Kong } \text { et al., 2017 }\end{array}$ \\
\hline $\begin{array}{l}\text { Azotobacter } \\
\text { Bacillus } \\
\text { Pseudomonas } \\
\text { Rhizobium }\end{array}$ & $\begin{array}{l}\text { Phytoharomone } \\
\text { secretion }\end{array}$ & $\begin{array}{l}\text { Secrete a number of } \\
\text { phytoharmones helps in } \\
\text { plant growth promotion. } \\
\text { Makes easy to flow of } \\
\text { nutrients }\end{array}$ & Kong et al., 2017. \\
\hline $\begin{array}{l}\text { Bacillus } \\
\text { Psuedomonas } \\
\text { Streptomycetes }\end{array}$ & Biocontrol al., 2015 \\
\hline $\begin{array}{l}\text { Activation of defence } \\
\text { mechanism against plant } \\
\text { pathogens and makes } \\
\text { resistant against many } \\
\text { plant diseases }\end{array}$ & Schrey and Tarkka, 2008. \\
Wani et al., 2007
\end{tabular}

Fig.1

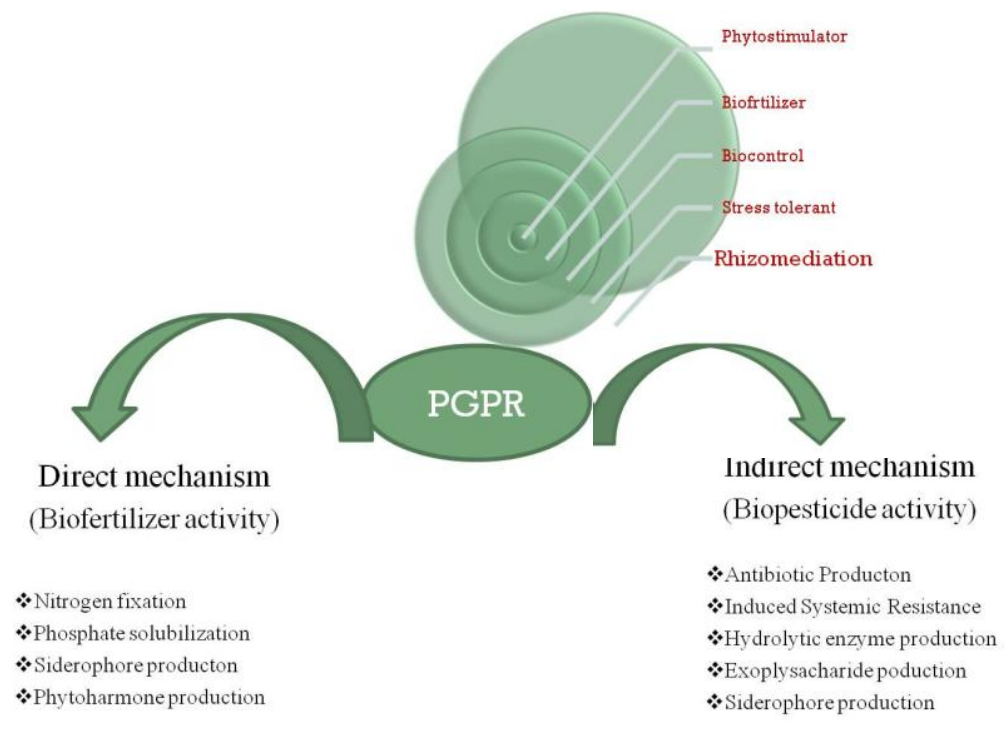




\section{Role of plant growth promoting rhizobacteria in agriculture as a biofertilizer}

Agriculture is major economics in many developing countries. Biofertilizer is the preparation of beneficial microbes formulation with carrier which helps plant growth promotion. It is reported by Kennedy and Klopler (1992) that by using biofertilizers in cereals can enhance plant growth and inhibit plant diseases that will results to promote the plant growth promotion and yield of the plants. But the use of biofertilizers is yet not well explored in many parts of developing regions of the world.

In conclusion enhancing agriculture productivity without harming the ecosystem is the key challenge for the agronomist. In this context, application of PGPR in agriculture can achieve the aim. PGPR have good impact in crop productivity in terms of biofertilizers, biocontrol, bioremediation and ecosystem functioning. Encouragement should be given to its implementation in agriculture. If the use of PGPR in the agricultural field is maximized, this will certainly prove to be highly beneficial and likely to become a renewable tool for the sustainable agriculture.

\section{References}

Abbott LK, Murphy DV (2007) Biological soil fertility: a key to sustainable land use in agriculture. Azospirillum. Aust J Plant Physiol 28:871-879

Ahemad M, Kibret M (2014) Mechanisms and applications of plant growth promoting rhizobacteria: current perspective. J King Saudi Univ Sci 26:1-20

Ahmed, A.; Hasnain, S. Auxin producing Bacillus sp.: Auxin quantification and effect on the growth Solanum tuberosum. Pure Appl. Chem. 2010, 82, 313-319. Biological Sciences, 3(6): 563-571.

Bailey-Serres, J., and Voesenek, L. A. (2008). Flooding stress: acclimations and genetic diversity. Annu. Rev. Plant Biol. 59, 313339. doi: 10.1146/annurev. arplant. 59.032607. 092752

Bhandari G (2014) An overview of agrochemicals and their effects on environment in Nepal. Appl Ecol Environ Sci., 2:66-73

Cassán F., Vanderleyden J., Spaepen S. (2014) Physiological and Agronomical Aspects of Phytohormone Production by Model Plant-Growth-Promoting Rhizobacteria (PGPR) Belonging to the Genus Azospirillum Journal of Plant Growth Regulation; 33(2): 440-459.

Cibichakravarthy, B., Preetha, R., Sundaram, S. P., Kumar, K., and Balachandar, D. (2012). Diazotrophic diversity in the rhizosphere of two exotic weed plants, Prosopis juliflora and Parthenium hysterophorus. World J. Microbiol. Biotechnol. 28, 605-613. doi: 10.1007/s11274-011-0853-9

Daane KM, Bentley WJ, Walton VM, et al., 2006. New controls investigated for vine mealybug. Cal Ag 60:31-8.

El-Nagdy GA, Nassar DMA, El-Kady EA, ElYamanee GSA. 2010. Response of flax plant (Linum usitatissimum L.) to treatments with mineral and bio-fertilizers from nitrogen and phosphorus. J Amer Sci 6: 10, 207-217

Farrar, K., Bryant, D., and Cope-Selby, N. (2014). Understanding and engineering beneficial plant-microbe interactions: plant growth promotion in energy crops. Plant Biotechnol. J. 12, 1193-1206. doi: 10.1111/pbi.12279. file:///C:/Users/ HP/Desktop/mini\%20review/AdvanceinP GPRResearch.pdf

Fletcher, D., Hanton, S., and Mellalieu, S. D. (2006). An organisational stress review: Conceptual and theoretical issues in competitive sport. In S. Hanton and S. D. Mellalieu (Eds.), Literature reviews in sport psychology (pp. 321-374). Hauppauge, NY: Nova Science

Gerhardson, B. 2002. Biological substitutes for pesticides. Trends Biotechnol. 20:338343.

Glick, B. 1995. The enhancement of plant growth by free-living bacteria. Can. J. Microbiol. $41,109-117$ 
Joseph B, Patra RR, Lawrence R (2007) Characterization of plant growth promoting Rhizobacteria associated with chickpea (Cicer arietinum L). Int J Plant Prod 1(2):141-152

Kapulnik, Y., (1991): Plant growth-promoting rhizobacteria, p. 717-729. In: Y. Waisel; A. Eshel and V. Kafkafi (eds.). Plant roots, the hidden half. Marcel Dekker, New York.

Kizilkaya R (2009) Nitrogen fixation capacity of Azotobacter spp. Strains isolated from soils in different ecosystems and relationship between them and the microbiological properties of soils. J Environ Biol., 30(1): 73-82

Kloepper, J. W., Zablotowicz, R. M., Tipping, E. M. and Lishitz, R. (1991): D.L. Keister and P.B. Cregan. p. 315-326. Kluwer Academic Publishers. Dordrecht. The Netherlands.

Kong, Z., Deng, Z., Glick, B.R., Wei, G., Chou, M., 2017. A nodule endophytic plant growth-promoting Pseudomonas and its effects on growth, nodulation and metal uptake in Medicago lupulina under copper stress. Ann. Microbiol. 67, 49-58.

LAZAROVITS, G.; NOWAK, J. Rhizobacteria for improvement of plant growth and establishment. HortScience, v. 32, n. 2, p. 188-192, 1997.

Liu D, Lian B, Dong H (2012) Isolation of Paenibacillus sp. and assessment of its potential for enhancing mineral weathering. Geomicrobiol J 29(5):413421

Maheshwari, D.K. (2010.): Plant Growth and Health Promoting Bacteria, Microbiology Monographs. Springer.

Mishra J and Arora NK (2016) Bioformulations for plant growth promotion and combating phytopathogens: a sustainable approach. In: Bioformulations: for sustainable agriculture. Springer, India, pp 3-33

Mishra J, Tewari S, Singh S, Arora NK (2015) Biopesticides where we stand? In: Arora NK (ed) Plant microbe symbiosis: applied facets. Springer, New Delhi, pp 37-75

Nguyen, D., Rieu, I., Mariani, C., and van Dam, N. M. (2016). How plants handle multiple stresses: hormonal interactions underlying responses to abiotic stress and insect herbivory. Plant Mol. Biol. 91, 727-740. doi: 10.1007/s11103-016- 0481-8

Rajasekaran, S., K. Sankar Ganesh, K. Jayakumar, M. Rajesh, C. Bhaaskaran and P. Sundaramoorthy (2012)

Riadh, K., Wided, M., Hans-Werner, K., and Chedly, A. (2010). Responses of halophytes to environmental stresses with special emphasis to salinity. Adv. Bot. Res. 53, 117-145. doi: 10.1016/S00652296(10)53004-0

Segura, A., and Ramos J L 2013. Plantbacteria interactions in the removal of pollutants. $\mathrm{J}$ Curr Opinion Biotechnol., 24: 467-73

Soe, KM, Bhromsiri, A, Karladee, D and Yamakawa, T. 2012. Effects of endophytic actinomycetes and Bradyrhizobium japonicum strains on growth, nodulation, nitrogen fixation and seed weight of different soybean varieties. Soil Sci. Plant Nutr., 58: 319-325.

Sorty, A. M., Meena, K. K., Choudhary, K., Bitla, U. M., Minhas, P. S., and Krishnani, K. K. (2016).

Turner, T. R., James, E. K., and Poole, P. S. (2013a). The plant microbiome. Genome Biol. 14:209. doi: 10.1186/gb-2013-14-6209

Zhuang, Z.H., Zhou, Y., Yu, M.C., Silverman, N., Ge, B.X. (2007).

\section{How to cite this article:}

Kusum Sharma, Swati Sharma and Rajendra Prasad, S. 2019. PGPR: Renewable Tool for Sustainable Agriculture. Int.J.Curr.Microbiol.App.Sci. 8(01): 525-530.

doi: https://doi.org/10.20546/ijcmas.2019.801.058 